\title{
UJI KEMAMPUAN RENDAMAN KULIT BUAH JERUK NIPIS (CITRUS AURANTIFOLIA) TERHADAP PENGENDALIAN KECOA
}

\author{
Anisa Filanita ${ }^{1)}$
}

\begin{abstract}
Abstrak
Kecoa merupakan serangga yang seringkali mengganggu kenyamanan hidup manusia serta menyebarkan berbagai patogen penyakit. Beberapa penyakit yang ditularkan oleh kecoa diantaranya tipus, diare, hepatitis, asma, dan kolera. Pada umumnya pengendalian kecoa dilakukan dengan menyemprot insektisida sintesis. Penggunaan insektisida sintesis memang memiliki beberapa keuntungan seperti kemudahan dalam mengoprasikannya, efektivitas yang tinggi, daya kerja yang cepat, dapat digunakan setiap waktu, serta mudah diperoleh. Namun penggunaan insektisida yang tidak tepat dan berlebihan secara terus menerus dapat menimbulkan resistensi dan pencemaran lingkungan. Oleh karena itu, diperlukan insektisida alternatif untuk mengendalikan kecoa agar tidak mencemari lingkungan dan dapat mengurangi resiko kontaminasi residu pestisida. Insektisida alternatif yang sedang dikembangkan adalah pemanfaatan tumbuh-tumbuhan seperti bunga, daun, akar, kulit dan biji dihancurkan dan kemudian langsung digunakan sebagai insektisida atau bahan beracun yang diektraksi terlebih dahulu kemudian baru digunakan sebagai insektisida botani.

Penelitian ini merupakan penelitian true eksperimen dengan melakukan pengamatan terhadap pemanfaatan rendaman kulit jeruk nipis (Citrus aurantiifolia) terhadap pengendalian kecoa. Pada penelitian ini dilakukan pengamatan terhadap jumlah kematian kecoa yang telah disemprot menggunakan berbagai konsentrasi kulit jeruk nipis, yaitu $0 \%$ (kontrol), 40\%, 50\%, 60\% dan $70 \%$ pada setiap kotak.

Dari hasil penelitian efektifitas rendaman kulit jeruk nipis (Citrus aurantiifolia) terhadap pengendalian kecoa dengan masing-masing konsetrasi), 40\%,50\%, 60\% dan $70 \%$ menujukkan hasil presentase dimana pada konsentrasi $40 \%$ jumlah kecoa yang mati sebesar $57 \%$, konsentrasi $50 \%$ jumlah kecoa yang mati sebesar $71 \%$, konsentrasi $60 \%$ jumlah kecoa yang mati sebesar $86 \%$ dan konsentrasi $70 \%$ jumlah kecoa yang mati sebesar 100\%. Sehingga semakin tinggi konsentrasi yang digunakan maka semakin tinggi kematian kecoa yang dihasilkan.
\end{abstract}

Kata Kunci : Kulit Jeruk Nipis, kecoa

${ }^{1)}$ Alumni Prodi D3 Kesehatan Lingkungan Poltekkes Tanjungkarang

\section{PENDAHULUAN}

Kesehatan lingkungan merupakan faktor penting dalam unsur penentu atau determinan dalam kesejahteraan penduduk. Di mana lingkungan yang sehat sangat dibutuhkan bukan hanya untuk meningkatkan derajat kesehatan masyarakat, tetapi juga untuk kenyamanan hidup dan meningkatkan efisiensi kerja dan belajar. Lingkungan yang sehat adalah lingkungan yang terhindar dari hal - hal yang menyebabkan gangguan kesehatan, salah satunya yaitu terhindar dari bintang pengganggu yang dapat menimbulkan berbagai penyakit dari binatang tersebut seperti kecoa. Menurut (Rozendaal, 1997 dalam Ginting, Br, 2014) dikatakan bahwa kecoa memberikan efek negatif lebih terhadap manusia dibandingkan dengan serangga lain. Mereka cenderung memuntahkan makanan yang sudah dicerna sebagian dan terus menerus mengeluarkan feses ketika sedang makan. Kebiasaan tersebut yang berperan sebagai pembawa penyakit seperti, demam typoid, kolera, polio, disentri amuba, diare, infeksi saluran kencing, dan infeksi hati. Di beberapa Negara, terdapat orang-orang yang alergi terhadap keberadaan kecoa.

Penyakit diare merupakan penyakit yang ditularkan oleh kecoa melalui makanan dan minuman, berbagai kuman penyakit yang berasal dari tempat-tempat kotor menempel pada tubuh kecoa dan menempel di setiap tempat yang dia hinggapi. Penyakit diare merupakan masalah kesehatan di Indonesia termasuk di Propinsi Lampung maupun di Kota 
Bandar Lampung. Trend kasus diare di Kota Bandar Lampung untuk semua umur pada tahun 2014 - 2015 cenderung terjadi peningkatan. Dimana kasus diare untuk semua umur pada tahun 2014 sebanyak 17.605 kasus sementara pada tahun 2015 sebanyak 18.231 kasus (Dinkes Bandar Lampung, 2015 ).

Di dunia terdapat kurang lebih 4.500 species kecoa, 4 (empat) spesies diantaranya umum ditemukan di dalam rumah yaitu Periplaneta americana, Blattela germanica, Blatta orientalis, dan Supella langipalpa (Depkes, 2012). Dalam tubuh kecoa pernah ditemukan lebih dari 40 mikroorganisme, seperti Pastreulla pestis, Shigella dysentriae, Microbacterium tuberculosis, Salmonella typhosa dan lain sebagainya. Bahkan dalam tubuh kecoa juga pernah ditemukan jenis virus seperti virus polio. Pada tinja kecoa juga terdapat zat-zat karsinogenik seperti kynurenic, xanturenic, dan 8-hydroxyquinaldic acids. Oleh sebab itu diperlukan pengendalian terhadap populasi kecoa (Mullins dan Cochran dalam Oktariani, 2002).

Pada umumnya pengendalian kecoa dilakukan dengan menyemprot insektisida sintesis. Penggunaan insektisida sintesis memang memiliki beberapa keuntungan seperti kemudahan dalam mengoprasikannya, efektivitas yang tinggi, daya kerja yang cepat, dapat digunakan setiap waktu, serta mudah diperoleh. Namun penggunaan insektisida yang tidak tepat dan berlebihan secara terus menerus dapat mengakibatkan terjadinya resistensi pada serangga terhadap insektisida tersebut. Selain itu pula, insektisida akan meninggalkan residu yang dapat mengkontaminasi organisme lain serta lingkungan sekitar. Akibat dampak negatif yang ditimbulkan oleh penggunaan insektisida, maka dibutuhkan solusi baru untuk pengendalian serangga hama dan vektor penyakit yang ramah lingkungan.

Berdasarkan cara masuk ke dalam tubuh serangga, insektisida dapat dibedakan atas racun pernafasan (fumigants), racun kontak dan racun perat. Fumigants digunakan untuk membunuh serangga tanpa harus memperhatikan bentuk mulutnya. Insektisida ini berbentuk gas. Penggunaan insektisida ini harus hati-hati terutama penggunaan di ruang tertutup. Insektisida sebagai racun kontak, yang terpenting adalah kontak antara serangga yang ingin dibunuh dengan insektisida yang digunakan. Insektisida sebagai racun perut berarti insektisida harus masuk melalui mulut.
Serangga yang diberantas dengan insetisida ini biasanya mempunyai bentuk mulut menggigit lekat isap dan bentuk mengisap (Depkes RI, 2002).

Oleh karena itu, diperlukan insektisida alternatif untuk mengendalikan kecoa agar tidak mencemari lingkungan dan dapat mengurangi resiko kontaminasi residu pestisida. Insektisida alternatif yang sedang dikembangi adalah pemanfaatan tumbuh-tumbuhan seperti bunga, daun, akar, dan biji dihancurkan dan kemudian langsung digunakan sebagai insektisida atau bahan beracun yang diektraksi terlebih dahulu kemudian baru digunakan sebagai insektisida botani.

Zat aktif insektisida berbahan baku alami yang diperoleh dari tumbuh-tumbuhan menjadi salah satu alternatif yang semakin dipertimbangkan, misalnya penggunaan tanaman jenis tertentu sebagai pengusir atau penolak serangga. Salah satu caranya adalah dengan memanfaatkan tanaman jeruk nipis (Citrus aurantiifolia).

Kelebihan pestisida nabati dibandingkan dengan pestisida sintetik adalah pada senyawa yang terkandung di dalamnya. Dalam suatu ekstrak tumbuhan, selain beberapa senyawa aktif utama biasanya juga banyak terdapat senyawa lain yang kurang aktif, tetapi keberadaanya dapat meningkatkan aktivitas esktrak secara keseluruhan. Hal ini memungkinkan serangga tidak mudah menjadi resisten, karena kemampuan serangga membentuk sistem pertahanan terhadap beberapa senyawa yang berbeda secara bersamaan lebih kecil dari pada senyawa insektisida tunggal (Murdani, Rina 2014).

Di Indonesia, Lesmana (2003) telah melakukan uji efektifitas repelensi ekstrak sepuluh tanaman terhadap kecoa jenis Blatella germanica. Kesepuluh tanaman tersebut antara lain jeringau, kapulaga, serai dapur, F.vulgare, lawang, Lantana camara $\mathrm{L}$, pandan, sirih, nilam dan akar wangi pada konsentrasi $0 \%, 1 \%, 3 \%$ dan $5 \%$ yang semuanya bersifat repellent terhadap Blatella germanica. Selain Lesmana (2003), peneliti lain yaitu Oktariani (2002) juga pernah melakukan penelitian mengenai efektifitas serbuk biji lada hitam (Piper nigrum) sebagai repellent terhadap kecoa jenis Periplaneta americana. Dosis yang digunakan yaitu dosis $1 \mathrm{gr}, 2 \mathrm{gr}, 3 \mathrm{gr}$, dan 4 gr dengan 4 kali pengulangan. Dosis yang paling efektif sebagai repellent yaitu dosis 3 gr yang mampu menolak kecoa Periplaneta americana hingga 
$85 \%$. Pada penelitian dr.Aswin, dkk mengenai uji potensi ekstrak kulit jeruk nipis sebagai pengusir kecoa yang menggunakan kosentrasi $30 \%, 40 \%$ dan $50 \%$ menyimpulkan bahwa konsentrasi yang efektif mengusir kecoa adalah $40 \%$ dan $50 \%$.

Tanaman jeruk nipis (Citrus aurantifolia) mengandung zat-zat seperti saponin, sitronela, linalil asetat, senyawa flavonoid dan zat-zat lain. Kulit buah jeruk dapat berpotensi menjadi repellent ( zat penolak ) karena mengandung minyak atsiri dengan komponen limonene, mirsen, linalool, oktanal, decanal, sitronelol, neral, geraniol, valensen, sinnsial dan sinensial. Linalol, citronellal dan geraniol termasuk senyawa yang bersifat repellent terhadap artropoda (Inayah, 2007). Kulit jeruk nipis mempunyai efek insektisida pada hewan serangga. Zat aktif yang berfungsi sebagai insektisida adalah zat D-limone (70-90\%). Senyawa D-limone merupakan senyawa dominan dalam minyak atsiri jeruk yang dapat menimbulkan efek negatif terhadap serangga yaitu dengan meracuni serangga (knock down) kemudian mengganggu syaraf (blockade) serangga. Senyawa $D$-limone telah dibuktikan dalam beberapa penilitian dengan memberikan efek insektisida terhadap beberapa jenis serangga.

Berdasarkan uraian diatas, maka mendorong penulis untuk melakukan penelitian mengenai Uji Efektifitas Rendaman Kulit Buah Jeruk Nipis (Citrus Aurantifolia) terhadap pengendalian kecoa dewasa dengan menggunakan konsentrasi yang berbeda- beda.

\section{METODE}

Jenis Penelitian ini menggunakan desain penelitian eksperimental. Pendekatan yang dipakai dalam penelitian ini adalah true experimental atau eksperimen sungguhan. Penelitian ini dilakukan di workshop Politeknik Kesehatan Lingkungan Tanjung Karang Jurusan Kesehatan Lingkungan dan waktu penelitian pada bulan Juni 2017. Tahapan penelitian meliputi :

1. Persiapan penelitian

a. Peralatan dan bahan untuk mendapatkan konsentrasi larutan rendaman kulit jeruk nipis (Citrus Aurantifolia)

- Pisau untuk memisahkan kulit dari buah jeruk nipis

- Timbangan untuk menimbang kulit buah jeruk nipis
- Labu ukur sebagai perbandingan antara larutan rendaman jeruk nipis dengan air

- Gelas ukur untuk mengukur larutan rendaman dan mengukur air

- Saringan dan kain untuk menyaring hasil larutan kulit buah jeruk nipis

- Blender untuk menghaluskan kulit buah jeruk nipis

- Botol semprot sebagai tempat penyimpan larutan rendaman kulit jeruk nipis dan aquadest

b. Pembuatan konsentrasi larutan rendaman kulit jeruk nipis (Citrus Aurantifolia) sebagai berikut:

- Siapkan alat dan bahan

- Pisahkan kulit dengan buah jeruk nipis menggunakan pisau

- Timbang kulit jeruk nipis sebanyak 1000 gram, kemudian dicuci sampai bersih.

- Haluskan kulit buah jeruk nipis menggunakan blender

- Masukan kedalam wadah dan tambahkan air sebanyak $1000 \mathrm{ml}$ atau dengan perbandingan 1:1

- Biarkan serbuk kulit buah jeruk nipis direndam dalam air sampai 3 hari (setiap hari dihomogenkan)

- Setelah tiga hari saring rendaman kulit jeruk nipis dengan menggunakan saringan dan kain

- Hasil saringan dibagi menjadi lima konsentrasi rendaman kulit jeruk nipis (Citrus Aurantifolia) yaitu konsentrasi $0 \%$ (kontrol) $40 \%, 50 \%, 60 \%$ dan $70 \%$

- Volume larutan kulit buah jeruk nipis yang diambil dengan rumus penggenceran yaitu $V_{1} . \% \%_{1}=V_{2} . \% \%_{2}$

2. Pelaksanaan penelitian .

a. Pemberantasan (mortalitas) kecoa dilakukan di Workshop Politeknik Kesehatan Lingkungan Tanjung Karang, dengan mengumpulkan kecoa kemudian masukkan kedalam kotak berukuran $20 \mathrm{x}$ $26 \mathrm{~cm}(0 \%$ (kontrol) $40 \%, 50 \%, 60 \%$ dan $70 \%$ ), masing- masing kotak diisi kecoa sebanyak 7 ekor kecoa.

b. Mortalitas kecoa dengan berbagai konsentasi larutan rendaman kulit jeruk nipis (Citrus Aurantifolia) sebagai berikut: 
1) Dilakukan penyemprotan dengan tiga kali pengulangan pada masing-masing kotak ( $0 \%$ (kontrol) $40 \%, 50 \%, 60 \%$ dan $70 \%$ ) dengan lima larutan konsentrasi yaitu konsentrasi $0 \%$ ( 100 $\mathrm{ml}$ aquadest) konsentrasi $40 \%$ (campuran $40 \mathrm{ml}$ larutan rendaman kulit jeruk nipis $+60 \mathrm{ml}$ aquades), $50 \%$ (campuran $50 \mathrm{ml}$ larutan rendaman kulit jeruk nipis $+50 \mathrm{ml}$ aquadest), konsentrasi $60 \%$ (campuran $60 \mathrm{ml}$ larutan rendaman kulit jeruk nipis +40 $\mathrm{ml}$ aguadest), dan konsentrasi $70 \%$ (campuran $70 \mathrm{ml}$ larutan rendaman kulit jeruk nipis $+30 \mathrm{ml}$ aguadest).

2) Dilakukan pengamatan selama 12 jam (waktu kontak 1 jam, 4jam, 8 jam, 12 jam) dengan tiga kali pengulang yaitu setiap 12 jam dilakukan satu kali penyemprotan dengan 7 kali semprotan konsentrasi larutan rendaman kulit jeruk nipis (Citrus Aurantifolia), dan menghitung jumlah kecoa yang mengalami kematian (mortalitas) pada masing - masing kotak ( $0 \%$ (kontrol) $40 \%, 50 \%, 60 \%$ dan $70 \%$ ).

\section{HASIL}

Dari hasil penelitian yang telah dilakukan di Workshop Politeknik Kesehatan Lingkungan Tanjung Karang Jurusan Keschatan Lingkungan pada bulan juni 2017 mengenai "Uji kempuan Rendaman Kulit Buah Jeruk Nipis (Citrus Aurantifolia) Terhadap Pengendalian Kecoa" Penelitian berlangsung pada tanggal 07 Juni - 09 Juni 2017 mulai pukul 07.00 WIB sampai dengan pukul 19.00 WIB. Pada penelitian ini dilakukan pengamatan terhadap jumlah kematian kecoa dengan metode spraying atau dengan penyemprotan pada setiap kotak dengan berbagai konsentrasi yaitu $0 \%$ sebagai kontrol, $40 \%, 50 \%, 60 \%$, dan $70 \%$.

Dari hasil penelitian yang diperoleh, menunjukan hasil bahwa pada setiap konsentrasi terdapat perbedaan jumlah kematian kecoa setelah diberikan perlakuan selama 12 jam dengan 3 kali pengulangan. Setiap perlakuan konsentrasi dalam penelitian ini menggunakan jumlah sampel kecoa yang sama yaitu 7 kecoa yang di masukan kedalam kotak yang berukuran $20 \times 26 \mathrm{~cm}$ dan setiap 12 jam dilakukan satu kali penyemprotan dengan tujuh semprotan konsentrasi larutan rendaman kulit buah jeruk nipis dan menghitung data jumlah kecoa yang mengalami kematian pada masingmasing kotak $(0 \%$ sebagai kontrol, $40 \%, 50 \%$, $60 \%$, dan $70 \%$ ) disajikan pada tabel dan grafik.

Tabel 1. Jumlah Kecoa yang Mati

\begin{tabular}{|c|c|c|c|c|c|c|c|}
\hline \multirow[t]{2}{*}{ Konsentrasi } & \multirow[t]{2}{*}{ Perlakukan } & \multirow{2}{*}{$\begin{array}{c}\text { Jumlah } \\
\text { kecoa }\end{array}$} & \multicolumn{4}{|c|}{ Waktu kontak } & \multirow[t]{2}{*}{ Komulatif } \\
\hline & & & 1 jam & $4 \mathrm{jam}$ & $8 \mathrm{jam}$ & $12 \mathrm{jam}$ & \\
\hline \multirow[t]{4}{*}{$0 \%$ (Kontrol) } & I & $7 \mathrm{kecoa}$ & 0 & 0 & 0 & 0 & 0 \\
\hline & II & 7 kecoa & 0 & 0 & 0 & 0 & 0 \\
\hline & III & $7 \mathrm{kecod}$ & 0 & 0 & 0 & 0 & 0 \\
\hline & Persentase & & & & & & $0 \%$ \\
\hline \multirow[t]{5}{*}{$40 \%$} & I & 7 kecoa & 1 & 1 & - & 1 & 3 \\
\hline & II & 7 kecoa & 1 & 1 & 1 & 1 & 4 \\
\hline & III & $7 \mathrm{kecoa}$ & 1 & 1 & 1 & 1 & 4 \\
\hline & Persentase & & & & & & $57 \%$ \\
\hline & I & 7 kecoa & 1 & 1 & 1 & 1 & 4 \\
\hline \multirow[t]{3}{*}{$50 \%$} & II & 7 kecoa & 1 & 1 & 2 & 1 & 5 \\
\hline & III & $7 \mathrm{kecoa}$ & 2 & 1 & 1 & 1 & 5 \\
\hline & Persentase & & & & & & $71 \%$ \\
\hline \multirow[t]{4}{*}{$60 \%$} & I & $7 \mathrm{kecoa}$ & 2 & 1 & 1 & 2 & 6 \\
\hline & II & 7 kecoa & 2 & 1 & 2 & 1 & 6 \\
\hline & III & 7 kecoa & 2 & 2 & 1 & 1 & 6 \\
\hline & Persentase & & & & & & $86 \%$ \\
\hline \multirow[t]{4}{*}{$70 \%$} & I & 7 kecoa & 2 & 3 & 2 & - & 7 \\
\hline & II & 7 kecoa & 2 & 2 & 3 & - & 7 \\
\hline & III & 7 kecoa & 2 & 2 & 3 & - & 7 \\
\hline & Persentase & & & & & & $100 \%$ \\
\hline
\end{tabular}


Tabel 2. Persentase Jumlah Kecoa yang Mati

\begin{tabular}{|c|c|c|c|c|c|}
\hline \multirow[t]{2}{*}{ Pengulangan } & Kontrol $(0 \%)$ & $40 \%$ & $50 \%$ & $60 \%$ & $70 \%$ \\
\hline & $\sum$ kecoa mati & $\sum$ kecoa mati & $\sum$ kecoa mati & $\sum$ kecoa mati & $\sum$ kecoa mati \\
\hline 1 & 0 & 3 & 4 & 6 & 7 \\
\hline 2 & 0 & 4 & 5 & 6 & 7 \\
\hline 3 & 0 & 4 & 5 & 6 & 7 \\
\hline Total & 0 & 11 & 14 & 18 & 21 \\
\hline Persentase & $0 \%$ & $57 \%$ & $71 \%$ & $86 \%$ & $100 \%$ \\
\hline
\end{tabular}

Dari tabel jumlah kematian kecoa di atas, didapatkan data jumlah rata-rata kematian kecoa pada 3 kali pengulangan yang terangkum pada grafik di bawah ini.

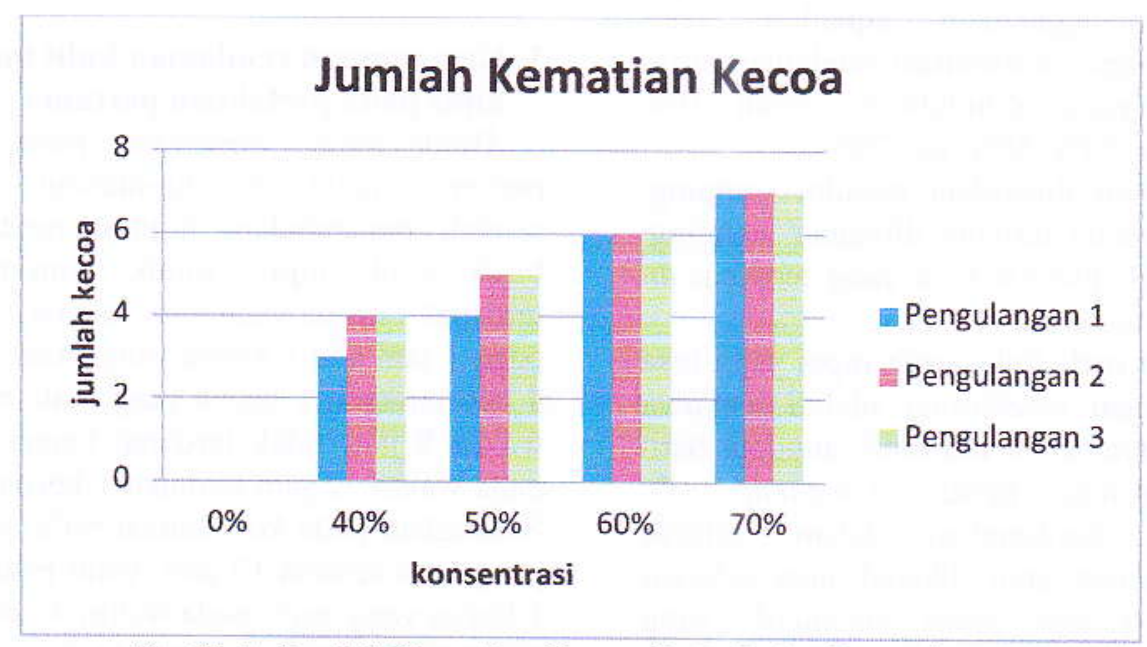

Grafik 1. Jumlah Kematian Kecoa Pada Setiap Pengulangan

Dari grafik diatas dapat diketahui bahwa kematian kecoa tertinggi berada di konsentrasi $70 \%$, yaitu 7 kecoa, sedangkan kematian kecoa terendah berada di konsentrasi $40 \%$ pada pengulangan 1 , yaitu sebanyak 3 kecoa dengan waktu kontak kematian 12 jam.

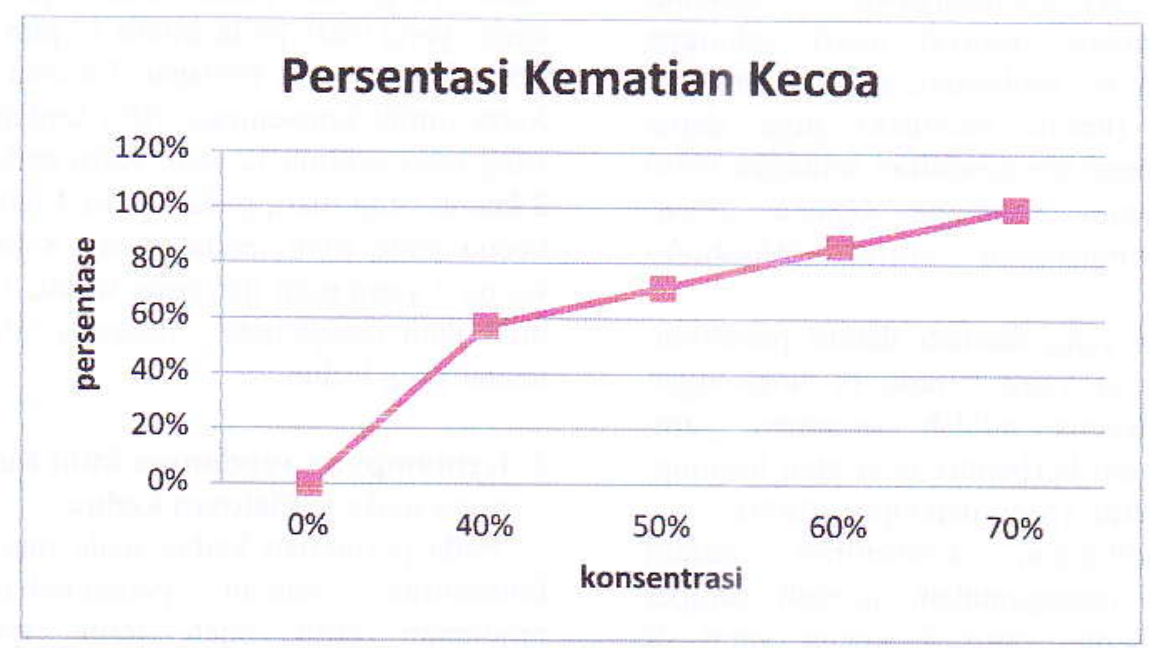

Grafik 2. Jumlah Persentasi Kematian Kecoa 3 kali pengulangan 
Dari grafik diatas dapat diketahui bahwa persentase kecoa tertinggi berada di konsentrasi $70 \%$, yaitu $100 \%$ sedangkan persentase kematian kecoa terendah berada di konsentrasi $40 \%$, yaitu $57 \%$ dengan waktu kontak kematian 12 jam.

\section{PEMBAHASAN}

Berdasarkan penelitian yang telah dilakukan, rendaman kulit jeruk nipis dibuat dengan cara memisahkan kulit jeruk nipis dari buah jeruk nipis yang kemudian dihancurkan dengan menggunakan blender setelah itu direndam selama 3 hari dan disaring menggunakan saringan dan kain untuk mendapatkan air rendaman kulit jeruk nipis. Setelah itu, air rendaman kulit jeruk nipis diencerkan menggunakan aquadest agar diperoleh berbagai konsentrasi rendaman kulit jeruk nipis yang dibutuhkan, yaitu $0 \%$ (kontrol), $40 \%, 50 \%, 60 \%$, dan $70 \%$.

Penyemprotan dilakukan melalui samping dikarenakan kecoa terletak dibagian samping atau menempel dikawat kasa yang terdapat di kotak berukuran $20 \times 26 \mathrm{~cm}$.

Kandungan pada kulit jeruk nipis yang bisa dijadikan sebagai insektesida adalah senyawa Limonene, senyawa ini termasuk anggota baru dalam insektisida nabati Limonene (DLimonene ) digolongkan dalam minyak ensensial tanaman atau dikenal juga sebagai floral atau scented plant chemical, yang diekstrak dari kulit jeruk dan efektif untuk mengendalikan serangga.

Ekstrak kulit jeruk nipis mengandungi senyawa d-Limonene dan sitronela yang meruap serta mengandungi aroma tajam (khasnya d-Limonene) yang tidak disukai oleh serangga. Senyawa-senyawa tersebut merupakan senyawa minyak atsiri, sehingga apabila minyak ini dioleskan, selain aromanya yang harum (untuk manusia) juga dapat digunakan sebagai pengendalian serangga yaitu dengan meracuni serangga (knock down) kemudian mengganggu syaraf (blockade) serangga.

Jenis kecoa yang diamati dalam penelitian ini adalah kecoa yang berada di lingkungan masyarakat. Kecoa adalah serangga yang berukuran $1-5 \mathrm{~cm}$ berbentuk oval atau lonjong, pipih dorsoventral. (Sigit dan Upik, 2006).

Setiap perlakuan konsentrasi dalam penelitian ini menggunakan jumlah sampel kecoa yang sama yaitu 7 kecoa yang di masukan kedalam kotak berukuran $20 \mathrm{~cm}$ x 26 cm. Kecoa yang mati ditandai dengan kecoa tidak bergerak apabila disentuh setelah disemprotkan selama 12 jam atau selama penelitian berlangsung. Dalam penelitian ini selain terdapat kecoa yang mati, pergerakan dari beberapa kecoa menjadi kurang aktif tetapi masih hidup meskipun sudah 12 jam.

Berdasarkan tabel dan grafik diatas, menunjukan hasil bahwa pada setiap konsentrasi terdapat perbedaan jumlah kematian kecoa setelah diberikan perlakuan selama 12 jam dengan 3 kali pengulangan. Selain itu, dapat dilihat bahwa pada kelompok larutan $0 \%$ tidak terjadi kematian pada kecoa hal ini membuktikan bahwa ada pengaruh pemberian rendaman kulit jeruk nipis terhadap kematian kecoa.

\section{Kemampuan rendaman kulit buah jeruk nipis pada perlakuan pertama}

Berdasarkan observasi pada perlakuan pertama pada masing-masing konsentrasi setelah penambahan larutan rendaman kulit buah jeruk nipis, untuk konsentrasi $40 \%$ terdapat 3 kecoa yang mati selama $12 \mathrm{jam}$, yaitu pada 1 jam ada 1 kecoa yang mati, pada waktu 4 jam terdapat 1 kecoa yang mati, namun pada waktu 8 jam tidak terdapat kecoa yang mati, pada waktu 12 jam terdapat 1 kecoa yang mati. Sedangkan pada konsentrasi $50 \%$ ada 4 kecoa yang mati selama $12 \mathrm{jam}$, yaitu pada 1 jam ada 1 kecoa yang mati, pada waktu 4 jam terdapat 1 kecoa yang mati, pada waktu 8 jam terdapat 1 kecoa yang mati, pada waktu 12 jam terdapat 1 kecoa yang mati. Konsentrasi $60 \%$ ada 6 kecoa yang mati selama 12 jam, yaitu pada 1 jam ada 2 kecoa yang mati, pada waktu 4 jam mengalami penurunan yaitu hanya terdapat 1 kecoa yang mati, pada waktu 8 jam terdapat 1 kecoa yang mati, pada waktu 12 jam mengalami peningkatan yaitu terdapat 2 kecoa yang mati. Serta untuk konsentrasi $70 \%$ terdapat 7 kecoa yang mati selama $12 \mathrm{jam}$, yaitu pada 1 jam ada 2 kecoa yang mati, pada waktu 4 jam terdapat 3 kecoa yang mati, pada waktu 8 jam terdapat kecoa 2 yang mati dan pada waktu 12 jam tidak dilakukan pengamatan dikarena tidak terdapat kecoa yang hidup.

\section{Kemampuan rendaman kulit buah jeruk nipis pada perlakuan kedua}

Pada perlakuan kedua pada masing-masing konsentrasi setelah penambahan larutan rendaman kulit buah jeruk nipis, untuk konsentrasi $40 \%$ setelah satu jam terdapat satu 
kecoa yang mati sama dengan perlakuan pertama terdapat satu kecoa yang mati, pada waktu 4 jam terjadi kematian satu kecoa, kemudian pada waktu 8 jam terdapat satu kematian kecoa berbeda dengan perlakuan pertama yaitu tidak terdapat kecoa yang mati dan pada waktu kontak 12 jam terdapat satu kecoa yang mati sehingga pada perlakuan kedua pada konsentrasi $40 \%$ terdapat 4 kecoa mati.

Sedangkan pada kosentrasi $50 \%$ ada 5 kecoa yang mati selama 12 jam jumlah ini lebih meningkat daripada perlakuan pertama diakarenakan pada waktu 8 jam pada perlakuan pertama hanya terdapat satu kecoa yang mati sedangkan pada percobaan kedua terdapa 2 kecoa yang mati, pada konsentrasi $60 \%$ terdapat 6 kecoa yang mati selama 12 jam jumlah ini sama dengan perlakuan pertama, pada konsentrasi $70 \%$ ada 7 kecoa yang mati selama 12 jam jumlah ini sama dengan perlakuan pertama yaitu pada waktu 8 jam seluruh kecoa dalam perlakuan mati.

\section{Kemampuan rendaman kulit buah jeruk nipis pada perlakuan ketiga \\ Pada perlakuan ketiga pada masing-masing} konsentrasi setelah penambahan larutan rendaman kulit buah jeruk nipis, untuk konsentrasi $40 \%$ setelah satu jam masih sama dengan percobaan pertama dan kedua terdapat satu kecoa yang mati, pada waktu 4 jam terjadi kematian satu kecoa, kemudian pada waktu 8 jam terdapat satu kematian kecoa dan pada waktu kontak 12 jam terdapat satu kecoa yang mati sehingga pada perlakuan ketiga pada konsentrasi $40 \%$ terdapat 4 kecoa mati.

Sedangkan pada kosentrasi $50 \%$ ada 5 kecoa yang mati selama 12 jam jumlah ini sama dengan perlakuan kedua, pada konsentrasi $60 \%$ terdapat 6 kecoa yang mati selama 12 jam jumlah ini sama dengan perlakuan kedua, pada konsentrasi $70 \%$ ada 7 kecoa yang mati selama 12 jam jumlah ini sama dengan perlakuan pertama dan perlakuan kedua yaitu pada waktu 8 jam seluruh kecoa dalam perlakuan mati.

Dari hasil persentase yang didapatkan untuk 3 kali perlakuan pada konsentrasi $0 \%$ nilai komulatif persentase yaitu $0 \%$. Konsentrasi $40 \%$ nilai komulatif persentase yaitu $57 \%$. Konsentrasi $50 \%$ nilai komulatif persentase yaitu $71 \%$. Konsentrasi $60 \%$ nilai komulatif persentase yaitu $86 \%$ dan Konsentrasi $70 \%$ nilai komulatif persentase yaitu $100 \%$. Hal ini menujukkan semakin tinggi konsentrasi maka semakin tinggi pula kematian kecoa.
Senyawa D-Limonene masuk melalui tubuh kecoa yang di dalamnya terdapat trakhea yaitu sistem pernapasan kecoa jadi semakin lama waktu kontak maka semakin berkurang senyawa D-Limonene yang masuk kedalam kecoa dikarenakan penguapan.

Penurunan potensi kematian kecoa untuk konsentrasi $40 \%$ pada waktu kontak 8 jam (jam 15.00) adalah di pengaruhi beberapa faktor diantaranya faktor ruangan yang tidak tertutup dengan rapi sehingga matahari dapat masuk ke ruangan yang mengakibatkan insektisida yang digunakan tidak stabil karena mengalami degradasi atau penguraian oleh matahari dan faktor pemyemprotan yang tidak merata pada setiap kosentrasi .

Dari segi kesehatan, tanaman jeruk nipis tidak berbahaya bagi kesehatan manusia sehingga tanaman jeruk nipis dapat dimanfaatkan sebagai pengobatan secara turun temurun. Jeruk nipis memiliki khasiat empiris sebagai obat batuk, obat penurun panas, dan obat pegel linu (Depkeskesos RI, 2001 dalam Putra, 2015).

Banyaknya manfaat jeruk nipis dalam kehidupan sehari-hari dapat mempermudah pengaplikasian rendaman kulit jeruk nipis ini sebagai pengendalian kecoa oleh masyarakat. Contohnya pengaplikasian dari rendaman kulit jeruk nipis ini adalah sebagai bahan pencampuran dalam pengharum ruangan, selain pengharum ruangan dapat pula menjadi pembasmi kecoa dalam ruangan yang terdapat kecoa. Pengaplikasian penelitian ini juga dapat menggunakan penyemprot dengan aerosol. Aerosol untuk sediaan semprotan kabut tipis dari sistem bertekanan tinggi. Penyemprotan dengan aerosol dapat menyemprot secara merata serta dapat mempermudah pengaplikasian.

\section{KESIMPULAN}

Hasil penelitian efektifitas rendaman kulit jeruk nipis (Citrus aurantiifolia) terhadap pengendalian kecoa dengan masing-masing konsetrasi), $40 \%, \quad 50 \%, \quad 60 \%$ dan $70 \%$ menujukkan hasil presentase dimana pada konsentrasi $40 \%$ jumlah kecoa yang mati sebesar $57 \%$, konsentrasi $50 \%$ jumlah kecoa yang mati sebesar $71 \%$, konsentrasi $60 \%$ jumlah kecoa yang mati sebesar $86 \%$ dan konsentrasi $70 \%$ jumlah kecoa yang mati sebesar $100 \%$. Sehingga semakin tinggi 
konsentrasi yang digunakan maka semakin tinggi kematian kecoa yang dihasilkan.

\section{DAFTAR PUSTAKA}

Albrigo, LG dan Carter, RD. 1977. Structure of Citrus Fruits In Relation To Processing. Connecticut : the AVI publishing compny inc. Tersedia di Al Anshori, Nidiamelati, dkk, 2014. Pemanfaata MinyakAtsiri Dari Ekstraksi Limbah Kulit Jeruk Nipis (Citrus Aurantifolia) Untuk Pengendalian Laiat Buah (Bactrocea sp). Universitas Sebelas Maret Surakarta

Baskoro. A.D., dkk. (2010). Uji Potensi Ekstrak Kulit Jeruk Nipis (Citus aurantifolia) sebagai Pengusir (Repellent) Kecoak (Periplenata americanus). Jurnal FKUB.

Depkes RI, 2002. Pengendalian kecoa tersedia http://repository.usu.ac.id/bitstream/ 123456789/62954/4/Chapter \%20II.pdf [26 februari 2017]

Depkeskesos RI, 2001, tersedia Putri, A. 2015. Efektivitas Ekstrak Daun Pandan Wangi (Pandanus Amaryllifolius, Roxb.) Sebagai Ovisida Aedes Aegypti (Linn.). Fakultas Kedokteran Universitas Lampung Bandar Lampung

Dinata, 2011.Tersedia (Rustle, Mena \& Syahrial. 2012. Uji Efektifitas Larutan Kulit Jeruk Manis Dan Larutan Daun Nimbi Untuk Mengendalikan Spodoptera Litura. (Lepidoptera : Noctuidae )Pada Tanman Sawi Dilapangan. Falkutas Pertanian USU)

Dinas Kesehatan Kota Bandar Lampung. 2015. ProfilKesehatan Kota Bandar Lampung

dr. Ir. Baehaki, SE. 2005. Insektisida Pengendalian Hama Tanaman. Bandung. 148 halaman

Erviana,Rika. 2014. Uji Potensi Kulit Buah Duku (Lansium Domesticum) Terhadap Mortalitas Kecoa Amerika (Periplaneta Americana) Dewasa. Fakultas Matematika Dan Ilmu Pengetahuan Alam Universitas Lampung

Ginting, Br; Evi Naria; Surya Dharma. 2014 .Efektifitas Serbuk Daun Spearmint (Mentha Spicata) Sebagai Repellent Terhadap Kecoa Rumah

Hanand, Nur, Novia, \& Nidia. 2014. PemanfaatanMinyak Atsiri DariEkstraksi
Limbah KulitJeruk Nipis

(CitrusAurantifolia) Untuk Pengendalian

Lalat Buah (BactroceraSp). Universitas Scbelas Maret Surakarta

http://digilib.unimus.ac.id/files/disk1/10/jtptuni mus-gdl-s1-2008-diahdwitap-488-3bab2.pdf [23 februari 2017]

https://www.academia.edu/9007207/KECOA 15 februari 2017]

Inayah, I.S. (2007) Mengenal Geraniol dan Sitronellol. http :// anekaplanta. wordpress.com/2007/12/26/mengenalgeran ioldan-sitronelol/, diakses tanggal 19 Januari 2017.

Kemenkes RI, 2011, tersedia Putri, A. 2015. Efektivitas Ekstrak Daun Pandan Wangi (Pandanus Amaryllifolius, Roxb.) Sebagai Ovisida Aedes Aegypti (Linn.). Fakultas Kedokteran Universitas Lampung Bandar Lampung

Kemenkes RI, 2012. Pedoman Penggunaan Insektisida (Pestisida)

Lota ML, Serra de DR, Tomi FL, Jacquemond C, Casanoca J. Volatile Components of Peel and Leaf Oils of Lemon and Lime Species. J. Agric. Food Chem; 2002, 50, 796-805 tersedia Santya, E. R. N. E dan J. Henry. 2013. Daya Proteksi Ekstrak Kulit Jeruk Purut (Cytrus hystrix) Terhadap Nyamuk Demam Berdarah.

Media, AR-Ruzz, 2016, Kitab Herbal Nusantara. Yogyakarta : 292 halaman.

Murdani, Rina. 2014, Keefektivan Daya Bunuh Ekstrak Daun JerukNipis(Citrus Aurantifolia)Terhadap Kematian Larva Nyamuk Aedes Aegypti Instar III. FakultasilmuKesehatan UniversitasMuhammadyah Surakarta.

Oktariani, Rini. 2002, Efektifitas Serbuk Biji Lada (Piper nigrum) Sebagai Repellent Terhadap Kecoa (Periplaneta americana). Fakultas Kesehatan Masyarakat Universitas Sumatera Utara. Pengembangan Sidik Jari Kromatografi Fitokimia Kulit Buah Jeru kNipis (Citrus Aurantifolia (Christm Swingle)) Dengan KLT Spektrofotodensitometri. Fakultas Matematika dan Ilmu Pengetahuan Alan Universitas Udayana.

Satya DS, Bayu. 2013. Koleksi Tumbuhan Berkhasiat. Yogyakarta. 256 halaman 
Siahaan, ParningotannaDameria. 2013. Kecoa ( Lipas/ Coro). Fakultas Pertanian Universitas Padjadjaran

Sigit, Singgih Harsoyodan Upik Kesumawati Hadi. 2006. Hama Permukiman Indonesia
Pengenalan, Biologi, dan Pengendalian. Fakultas Kedoteran Hewan Institut Pertanian Bogor 